\title{
Localisation of vascular endothelial growth factor and its receptors to cells of vascular and avascular epiretinal membranes
}

The Wilmer Eye Institute, Johns Hopkins University School of Medicine, Baltimore, Maryland, USA

Y-S Chen

SF Hackett

C-L Schoenfeld

MA Vinores

SA Vinores

PA Campochiaro

Department of Neuroscience, Johns Hopkins University School of Medicine, Baltimore, Maryland, USA

PA Campochiaro

Correspondence to: Peter A Campochiaro, MD, Maumenee 719, Johns

Hopkins University School of

Medicine, $600 \mathrm{~N}$ Wolfe

Street, Baltimore, MD

21287-9277, USA.

Accepted for publication 9 July 1997

Ying-Shan Chen, Sean F Hackett, Carl-Ludwig Schoenfeld, Melissa A Vinores, Stanley A Vinores, Peter A Campochiaro

\begin{abstract}
Aims/background-Epiretinal membranes (ERMs) arise from a variety of causes or, in some cases, for unknown reasons. Once established, ERMs tend to progress, becoming more extensive and exerting increasing traction along the inner surface of the retina. One possible cause for their progression is the production of growth factors by cells within ERMs that may provide autocrine or paracrine stimulation. Platelet derived growth factor (PDGF) and its receptors have been localised to cells of ERMs and may play such a role. In this study, comparative data were sought for several other growth factors that have been implicated in ERM formation.
\end{abstract}

Methods-Immunohistochemical staining of ERMs was done for PDGF-A, PDGF-B, basic fibroblast growth factor (bFGF), three isoforms of transforming growth factor $\beta$ (TGF- $\beta$ ), and vascular endothelial growth factor (VEGF) and its receptors, flt-1 and flk-1/KDR. Expression of flt-1 and flk-1/KDR was examined in cultured retinal pigmented epithelial (RPE) cells and retinal glia from postmortem eyes by immunohistochemistry and by reverse transcription coupled to polymerase chain reaction (RT-PCR).

Results-Staining was most intense and most frequently observed for VEGF and PDGF-A, both in vascular and avascular ERMs. The majority of cells stained for VEGF in nine of $11(81.8 \%)$ diabetic ERMs and in 14 of $24(58.3 \%)$ proliferative vitreoretinopathy ERMs. The receptors for VEGF, flt-1, and flk-1/KDR were also identified on cells in ERMs and on cultured RPE cells. By RT-PCR, mRNA for flt-1 was identified in RPE cells and retinal glia, and $\mathrm{mRNA}$ for flk-1/KDR was identified in RPE cells.

Conclusions-These data show that VEGF and its receptors are localised to both vascular and avascular ERMs and suggest that VEGF, like PDGF-A, may be an autocrine and paracrine stimulator that may contribute to progression of vascular and avascular ERMs.

(Br f Ophthalmol 1997;81:919-926)
Epiretinal membrane (ERM) formation, a process in which cells proliferate on the surface of the retina, is a major cause of visual loss. It occurs in association with several disease processes including ischaemic retinopathies, inflammatory eye disease, and retinal detachment. Idiopathic ERMs occur in the absence of a recognised associated disease. The ERMs in ischaemic retinopathies are vascularised, while those associated with retinal detachment and idiopathic ERMs are avascular. Therefore, they differ in that vascular endothelial cells play a prominent role in the former, but not the latter. However, they are similar with respect to the participation of other cells because in each type of ERM, retinal pigmented epithelial (RPE) cells and retinal glia are major components. ${ }^{1-5}$

Formation of ERMs in association with retinal detachment or after retinal reattachment surgery is called proliferative vitreoretinopathy (PVR); it is the most common cause for failure of retinal reattachment surgery. ${ }^{67}$ In this setting, there are several possible factors that could promote ERM formation, including loss of an inhibitory influence of the retina on RPE migration and proliferation, stimulatory factors released from detached retina, ${ }^{8}$ and breakdown of the blood-retinal barrier. ${ }^{910}$ Platelet derived growth factor (PDGF) may be one of the stimulatory factors. This is supported by the demonstration of a PDGF autocrine loop in RPE cells that is upregulated after retinal detachment. ${ }^{11}$

Ischaemic retinopathies, the most common of which is diabetic retinopathy, are diseases in which damage to retinal vessels results in areas of retinal non-perfusion. Ischaemic retina releases factors that stimulate retinal neovascularisation. Vascular endothelial growth factor (VEGF) is upregulated by hypoxia ${ }^{12}{ }^{13}$ and has been implicated as one of the stimulators of retinal neovascularisation. ${ }^{14-21}$ VEGF operates primarily through two tyrosine kinase receptors. The type 1 receptor is called fms-like tyrosine kinase-1 (ft- 1 ) and the type 2 receptor is called fetal liver kinase-1 (flk-1); its human counterpart is kinase insert domain containing receptor (KDR). ${ }^{22-24}$ Basic fibroblast growth factor may also play a role in retinal neovascularisation, although the evidence for this is less compelling. ${ }^{25}$ Once formed, both vascular and avascular ERMs tend to progress, even when the original inciting stimuli are decreased or eliminated. For instance, newly formed reti- 
Table 1 Primary antibodies

\begin{tabular}{|c|c|c|c|}
\hline Antibody & $\begin{array}{l}\text { Mouse monoclonal } \\
\text { (M) or rabbit } \\
\text { polyclonal }(R)\end{array}$ & Dilution & Source/reference \\
\hline \multicolumn{4}{|l|}{ Growth factors: } \\
\hline VEGF & $\mathrm{R}$ & $1: 20-1: 1000^{\star}$ & $\begin{array}{l}\text { Santa Cruz Biotechnology, Santa } \\
\text { Cruz, CA }\end{array}$ \\
\hline TGF- $\beta_{1}$ & $\mathrm{R}$ & $1: 500$ & Santa Cruz Biotechnology \\
\hline TGF- $\beta_{1}$ & $\mathrm{R}$ & $1: 400$ or $1: 500$ & $\operatorname{Ref} 35$ \\
\hline TGF- $\beta_{2}$ & $\mathrm{R}$ & $1: 400$ or $1: 500$ & Ref 35 \\
\hline TGF- $\beta_{3}$ & $\mathrm{R}$ & $1: 500$ & Ref 35 \\
\hline PDGF-A & $\mathrm{R}$ & $1: 100$ & Ref 36 \\
\hline PDGF-B & $M$ & $1: 50$ & Ref 37 \\
\hline bFGF & $\mathrm{R}$ & $1: 3000$ & Ref 38 \\
\hline bFGF & $M$ & $1: 50$ & Ref 39 \\
\hline \multicolumn{4}{|l|}{ Receptors: } \\
\hline Flt-1 & $\mathrm{R}$ & $1: 100$ & Santa Cruz Biotechnology \\
\hline Flk-1 (smaller peptide fragment) & $\mathrm{R}$ & $1: 100$ & Santa Cruz Biotechnology \\
\hline Flk-1 (overlapping, larger peptide fragment) & $\mathrm{R}$ & $1: 100$ & Santa Cruz Biotechnology \\
\hline \multicolumn{4}{|l|}{ Cell type identification markers: } \\
\hline Glial fibrillary acidic protein (GFAP) & $\mathrm{R}$ & $1: 1000$ & Dako, Santa Barbara, CA; Ref 40 \\
\hline Class III $\beta$ tubulin & M & $1: 500$ & $\operatorname{Ref} 41$ \\
\hline
\end{tabular}

${ }^{\star}$ Immunostaining for VEGF was seen at all dilutions of primary antibodies ranging from 1:20 to 1:1000 (1:20, 1:50, 1:100, 1:200, $1: 500$, and 1:1000). A dilution of $1: 20$ was used on specimens that were photographed because it enhanced the crispness of the staining without adding any background or false positive staining.

nal neovascularisation regresses after retinal hypoxia is decreased by panretinal photocoagulation (PRP), ${ }^{27}$ but well established retinal neovascularisation is less likely to regress and often progresses after PRP. Likewise, there is a tendency for progression of PVR and idiopathic ERMs. One possible reason is that the cells within ERMs produce growth factors that recruit other cells and stimulate cell proliferation. It has previously been demonstrated that cells of both vascular and avascular ERMs produce PDGF and have PDGF receptors ${ }^{11}{ }^{28}{ }^{29}$; therefore, PDGF may be one factor that contributes to the progression of ERMs. However, several other growth factors have also been localised in cells of ERMs (for review, see Campochiaro et $a l^{30}$ ). In this study, we performed immunohistochemical staining for several growth factors in vascular and avascular ERMs to obtain comparative information.

\section{Materials and methods}

EPIRETINAL MEMBRANE COLLECTION AND FIXATION

ERMs were promptly fixed after surgical excision and processed as previously described. ${ }^{29}$ They were incubated in $2 \%$ paraformaldehyde in phosphate buffered saline (PBS), $\mathrm{pH} 7.4$, containing $5 \%$ sucrose for 1 hour at room temperature. The sucrose concentration was increased stepwise to $20 \%$ and the specimens were frozen in a $2: 1$ ratio of $20 \%$ sucrose in PBS to OCT embedding compound (Miles, Elkhart, IN, USA) as previously described. ${ }^{31}$ Sections of $6 \mu \mathrm{m}$ were immersed in methanol containing $0.75 \%$ hydrogen peroxide for 10 minutes at $-20^{\circ} \mathrm{C}$, washed with $0.05 \mathrm{M}$ TRIS buffered saline, pH 7.6 (TBS), and blocked with $10 \%$ normal goat serum (NGS) in TBS for rabbit antibodies and $10 \%$ normal rabbit serum (NRS) in TBS for mouse antibodies before incubation with the primary antibody. Each ERM was stained for as many growth factors as possible, but when sufficient tissue was not available, priority was given to VEGF, TGF- $\beta_{1}$, TGF- $\beta_{2}$, or bFGF.
CELL CULTURE

RPE cell cultures were established by a previously described technique. ${ }^{32}$ Primary cultures were subcultured in Dulbecco's modified Eagle medium (DMEM, Gibco, Grand Island, NY, USA) containing $10 \%$ fetal bovine serum (FBS, Upstate Biotechnologies, Inc, Lake Placid, NY, USA). Cultures were demonstrated to be pure populations of RPE cells by immunohistochemical staining for cytokeratin. ${ }^{33}$

Human retinal glial cells were cultured and characterised as previously described. ${ }^{34}$ The cells were maintained in medium containing $40 \%$ DMEM $/ 40 \%$ Ham's F- $12 / 20 \%$ FBS and stained uniformly for glial fibrillary acidic protein, ${ }^{34}$ indicating that they contain a pure population of glial cells.

IMMUNOHISTOCHEMICAL STAINING

Sections were incubated at $4^{\circ} \mathrm{C}$ overnight with one of the primary antibodies listed in Table 1. When sufficient tissue was available, each ERM was stained for all growth factors and receptor types. The slides were warmed to room temperature and washed. Immunolabelling was visualised by HistoMark Red (Kirkegaard and Perry, Gaithersburg, MD, USA), which is an alkaline phosphatase based system that yields a brilliant red reaction product or by 3-amino-9-ethylcarbazole (AEC, Sigma, St Louis, MO, USA), which reacts with peroxidase to yield a brick red reaction product. HistoMark Red was developed according to the manufacturer's instructions. For AEC reaction, sections were immunoreacted as previously described $^{35}$ or as follows. The slides were incubated for 30 minutes with a 1:25 dilution of rabbit anti-mouse immunoglobulin in $1 \%$ NGS-TBS (Dako; Santa Barbara, CA, for mouse antibodies) or a 1:40 dilution of goat anti-rabbit globulins (Arnel, Brooklyn, NY; for rabbit antibodies). The slides were rinsed twice and incubated for 30 minutes with a 1:400 dilution of mouse peroxidase antiperoxidase complex (Arnel; for rabbit antibodies). After thorough washing with $0.05 \mathrm{M}$ TRIS, pH 7.6, 
the immunoreaction products were visualised by immunoperoxidase using freshly prepared $0.178 \mathrm{mg} / \mathrm{ml}$ AEC in $0.89 \mathrm{M}$ sodium acetate, pH 5.1, containing $2.1 \times 10^{-4} \%$ hydrogen peroxide for 10 minutes. Sections were coded so that the observer graded the specimens without knowledge of the type of ERM being evaluated. Immunohistochemical staining of each ERM with one of the growth factor antibodies was graded as: (1) 'none', if no cell stained, (2) 'sparse', if only occasional cells stained or if cell clusters stained, but only weakly, (3) 'prominent', if most cells stained or if clusters of cells stained intensely. Double labelling for VEGF and class III $\beta$ tubulin, which is a marker for identifying RPE cells in epiretinal membranes, ${ }^{41}$ was performed using AEC and HistoMark Black (Kirkegaard and Perry) as previously described. ${ }^{42}$

Cultured RPE or retinal glia were grown in slide wells and fixed in methanol. ${ }^{34}$ The wells were incubated with a 1:200 dilution of an affinity purified antibody directed against an amino terminal peptide fragment of VEGF (Santa Cruz Biotechnology, Santa Cruz, CA, USA), a 1:100 dilution of an affinity purified rabbit antibody raised against a peptide corresponding to a fragment of human flt-1 (Santa Cruz Biotechnology), or a 1:100 dilution of one of two affinity purified rabbit antibodies to flk-1 (Santa Cruz Biotechnology). One of the antibodies was an IgG generated against a 20 amino acid sequence from the carboxy terminus of mouse flk-1 and was used on the cell cultures. The other antibody was an IgG raised against a large peptide fragment that overlapped the first and showed a better cross reactivity with human flk-1/KDR. The second anti-flk-1 antibody was used on ERMs. The anti-flk-1 antibodies specifically immunoprecipitate $\mathrm{flk}-1^{4344}$ and immunocytochemical staining with the anti-flt-1 antibody colocalises with detection of flt- 1 mRNA by in situ hybridisation in cytotrophoblasts. ${ }^{45}{ }^{46}$ After overnight incubation at $4^{\circ} \mathrm{C}$ with the primary antibody, the slide wells were rinsed and the colour reaction was developed using Histo Mark Red according to the manufacturer's instructions (Kirkegaard and Perry).

For controls, the primary antibody was omitted and replaced with non-immune rabbit IgG (Jackson Immunoresearch, West Grove, PA, USA), non-immune rabbit serum (Arnel), or for VEGF, TGF- $\beta_{1}$, flt- 1 , and the flk-1/KDR antibodies generated against the smaller peptide fragment, the primary antibody was preincubated with a tenfold molar excess of the peptide against which the antibody was generated for 2.5 hours at room temperature or overnight at $4^{\circ} \mathrm{C}$ before its application to the slide. Immunohistochemistry for controls was otherwise performed identically.

Statistical significance was determined by the $\chi^{2}$ test.

REVERSE TRANSCRIPTION-POLYMERASE CHAIN REACTION (RT-PCR)

Total RNA was harvested by the procedure of Chomczynski and Sacchi. ${ }^{47}$ To harvest RPE RNA from postmortem human eyes, the ante- rior segment, vitreous, and retina were removed and the eye cup was washed with PBS and examined under a dissecting microscope to ascertain that no retinal fragments were present. Guanadinium lysis buffer was added to the eye cup and under a dissecting microscope, the RPE was brushed from Bruch's membrane and aspirated leaving Bruch's membrane intact, assuring isolation of pure RPE RNA.

Unique oligonucleotides for human flt-1 and flk-1 were synthesised by GeneLink (Thornwood, NY, USA). The sequence of the oligonucleotide for flt-1 spans the transmembrane region from nucleotide 1955 to 1979 (5'-AAGGAGAGGACCTGAAACTGTCTTG-3', upper) and from 2454 to 2475 (5'-ACTTTCCACAGAGCCCTTCTGG-3', lower) of the coding sequence. The oligonucleotides for flk- 1 span the transmembrane region from 2055 to 2074 (5'-ATGCACGGCATCTGGGAATC-3', upper) and 2568 to 2591 (5'GCTACTGTCCTGCA AGTTGCTGTC-3', lower). First strand cDNA synthesis was carried out using the Superscript kit (Gibco/ BRL) according to the manufacturer's instructions. PCR was performed using the Taq DNA polymerase (Gibco/BRL) for 32 cycles using an optimised annealing temperature and $\mathrm{MgCl}_{2}$ concentration. Reaction products were run on a $1.5 \% 3: 1$ SeaKem GTG agarose (FMC, Rockland, ME, USA) and stained with ethidium bromide for visualisation. PCR data are presented as the negative image of the ethidium bromide stained gels. The $521 \mathrm{bp}$ PCR product obtained from RPE RNA using flt-1 primers and the 537 bp PCR product obtained using flk-1 primers were subcloned. They were filled in with the Klenow fragment of DNA polymerase (Boehringer Mannheim, Indianapolis, IN, USA), purified by agarose gel electrophoresis, and then ligated into the EcoRV site of pCR-Script Amp SK (Stratagene, La Jolla, CA, USA). Subclones were checked by dideoxy DNA sequencing (Sequenase; US Biochemical, Cleveland, OH, USA).

\section{Results}

GROWTH FACTORS IN ERMS

Table 2 summarises the grading of cellular staining for each growth factor in ERMs from patients with PVR, PDR, or idiopathic macular pucker. Each growth factor studied (except TGF- $\beta 3$ in idiopathic macular pucker) showed some staining in all three types of ERMs, but the frequencies and intensities of staining varied considerably. As noted previously, ${ }^{29}$ most ERMs (regardless of the underlying disease process) stained for PDGF-A, many in clusters of cells. Prominent staining for PDGF-A was noted in five of six PDR ERMs and in four of eight PVR ERMs, with most of the cells positive for PDGF-A. PDGF-B staining was less conspicuous. Staining for VEGF was very similar to that for PDGF-A in PVR membranes, but was often more intense in PDR membranes (Fig 1A-C). The majority of cells stained for VEGF in nine of $11(81.8 \%)$ PDR membranes compared with 14 of 24 (58.4\%) PVR membranes (Fig 1D and E), and 
Table 2 Immunohistochemical staining for growth factors in cells of epiretinal membranes

\begin{tabular}{lclll}
\hline & $N$ & None (\%) & Sparse (\%) & Prominent (\%) \\
\hline $\begin{array}{l}\text { Proliferative diabetic retinopathy (PDR): } \\
\text { VEGF }\end{array}$ & 11 & $2(18.1)$ & $0(0)$ & \\
TGF- $\beta_{1}$ & 9 & $4(44.4)$ & $4(44.4)$ & $1(11.8)$ \\
TGF- $\beta_{2}$ & 9 & $2(22.2)$ & $4(44.4)$ & $3(33.3)$ \\
TGF- $\beta_{3}$ & 3 & $1(33.3)$ & $1(33.3)$ & $1(33.3)$ \\
PDGF-A & 6 & $1(16.7)$ & $0(0)$ & $5(83.3)$ \\
PDGF-B & 4 & $1(25.0)$ & $3(75.0)$ & $0(0)$ \\
bFGF & 8 & $3(37.5)$ & $5(62.5)$ & $0(0)$ \\
Proliferative vitreoretinopathy (PVR): & & & \\
VEGF & 24 & $1(4.2)$ & $9(37.5)$ & $14(58.3)$ \\
TGF- $\beta_{1}$ & 15 & $8(53.3)$ & $4(26.7)$ & $3(20)$ \\
TGF- $\beta_{2}$ & 14 & $6(42.9)$ & $7(50)$ & $31(7.1)$ \\
TGF- $\beta_{3}$ & 5 & $4(80)$ & $0(0)$ & $1(20)$ \\
PDGF-A & 8 & $0(0)$ & $4(50)$ & $4(50)$ \\
PDGF-B & 3 & $0(0)$ & $2(66.6)$ & $1(33.3)$ \\
bFGF & 9 & $5(45.5)$ & $3(27.3)$ & $1(9.1)$ \\
Idiopathic macular pucker: & 8 & $1(12.5)$ & $5(62.5)$ & $2(25)$ \\
VEGF & 7 & $1(14.3)$ & $6(85.7)$ & $0(0)$ \\
TGF- $\beta_{1}$ & 8 & $4(50)$ & $3(37.5)$ & $1(12.5)$ \\
TGF- $\beta_{2}$ & 3 & $3(100)$ & $0(0)$ & $0(0)$ \\
TGF- $\beta_{3}$ & 3 & $1(33.3)$ & $1(33.3)$ & $1(33.3)$ \\
PDGF-A & 7 & $2(28.6)$ & $4(57.1)$ & $1(14.3)$ \\
bFGF & & & & \\
\hline
\end{tabular}

two of eight $(25.0 \%)$ idiopathic ERMs (Figs $1 \mathrm{~F}$ and $2 \mathrm{~A})$. At least occasional cellular positivity for VEGF was seen in more than $80 \%$ of all ERMs examined. VEGF localisation in pigmented cells (Fig 3A) and its colocalisation with class III $\beta$ tubulin (Fig 3C) indicates that VEGF is present in RPE cells. Staining for bFGF, TGF- $\beta_{1}$ (Fig 2B) and TGF- $\beta_{2}$ (Fig 2C) was much less frequent and less extensive than staining for VEGF and
PDGF-A in the ERMs studied and very few ERMs stained with the antibody for TGF- $\beta_{3}$. However, occasional ERMs did show prominent staining for one of the less frequently observed factors.

GROWTH FACTOR RECEPTORS IN ERMS

Receptors for PDGF, as well as PDGF itself, are localised to vascular and avascular ERMs, suggesting that PDGF could play an autocrine and/or paracrine role in the progression of ERMs. ${ }^{11} 29$ Because the receptors for VEGF (flt-1 and flk-1/KDR) had been felt to be specifically expressed on vascular endothelial cells,${ }^{24}{ }^{48}$ we anticipated staining for flt-1 and flk-1/KDR in vascular, but not avascular, ERMs. However, flt-1 and flk-1/KDR were localised to both vascular ERMs from patients with PDR (3/4 for flt-1; 2/4 for flk-1) and avascular ERMs from patients with PVR or idiopathic macular pucker (15/20 for flt-1; 8/12 for flk-1) (Fig 4). When one type of VEGF receptor was found in a particular ERM, it was likely that the other type was also present $(\mathrm{p}=$ 0.013). Flt-1 was visualised on pigmented cells in ERMs (Fig 3B), indicating the presence of VEGF receptors on RPE cells. Prominent labelling for flt-1 also occurred on nearly all cells in ERMs consisting almost entirely of glial cells, as demonstrated by GFAP staining (Fig

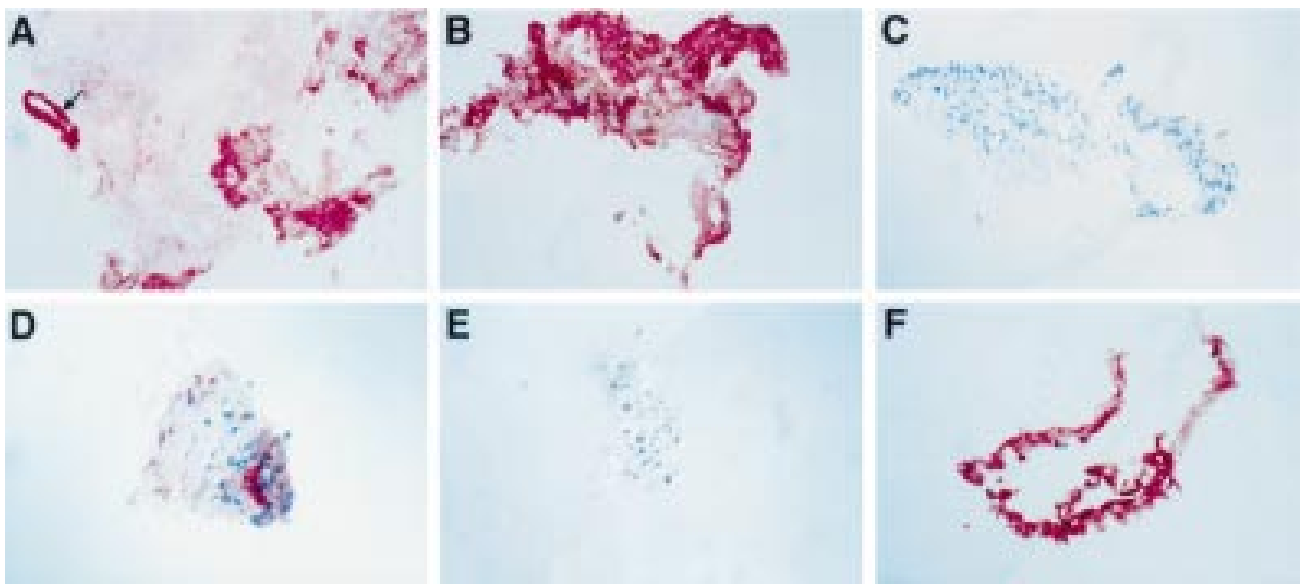

Figure 1 VEGF immunostaining in PDR, PVR, and idiopathic ERMs is visualised with a red reaction product. (A) An ERM from a patient with PDR shows prominent staining around a newly formed vessel (arrow), as well as in non-vascularised areas. (B) In an ERM from another patient with PDR, VEGF positivity is not limited to areas of neovascularisation, but is visualised in numerous other cells, including RPE cells (brown). (C) Preincubation of the primary antibody with the peptide against which it was generated (peptide control) eliminates VEGF immunostaining as seen on another section from the same ERM shown in (B). (D) VEGF staining is also demonstrated in a PVR ERM. (E) Preincubation of the primary antibody with the control peptide eliminates immunostaining in the same ERM shown in (D). (F) Most of the cells from an idiopathic ERM are also conspicuously stained for VEGF. (HistoMark Redihaematoxylin; $A, B, D, E, F \times 145, C \times 70)$.

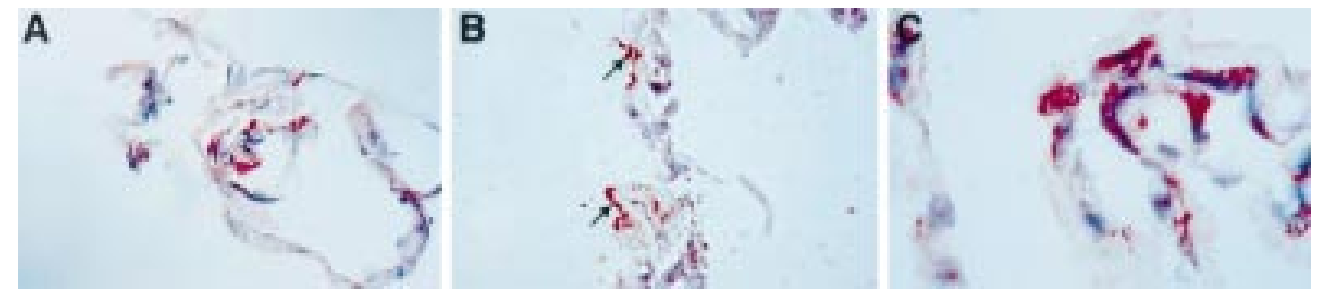

Figure 2 Immunostaining for multiple growth factors in a simple idiopathic ERM is visualised with a red reaction product. (A) Cellular positivity for VEGF (B) TGF- $\beta$, positivity (arrows) in cell processes from the same ERM. (C) Cellular staining for TGF- $\beta 2$ is also demonstrated in the same ERM. (A, C: HistoMark Red/haematoxylin; B: AEC/haematoxylin; $A \times 145 ; B, C \times 360$ ). 

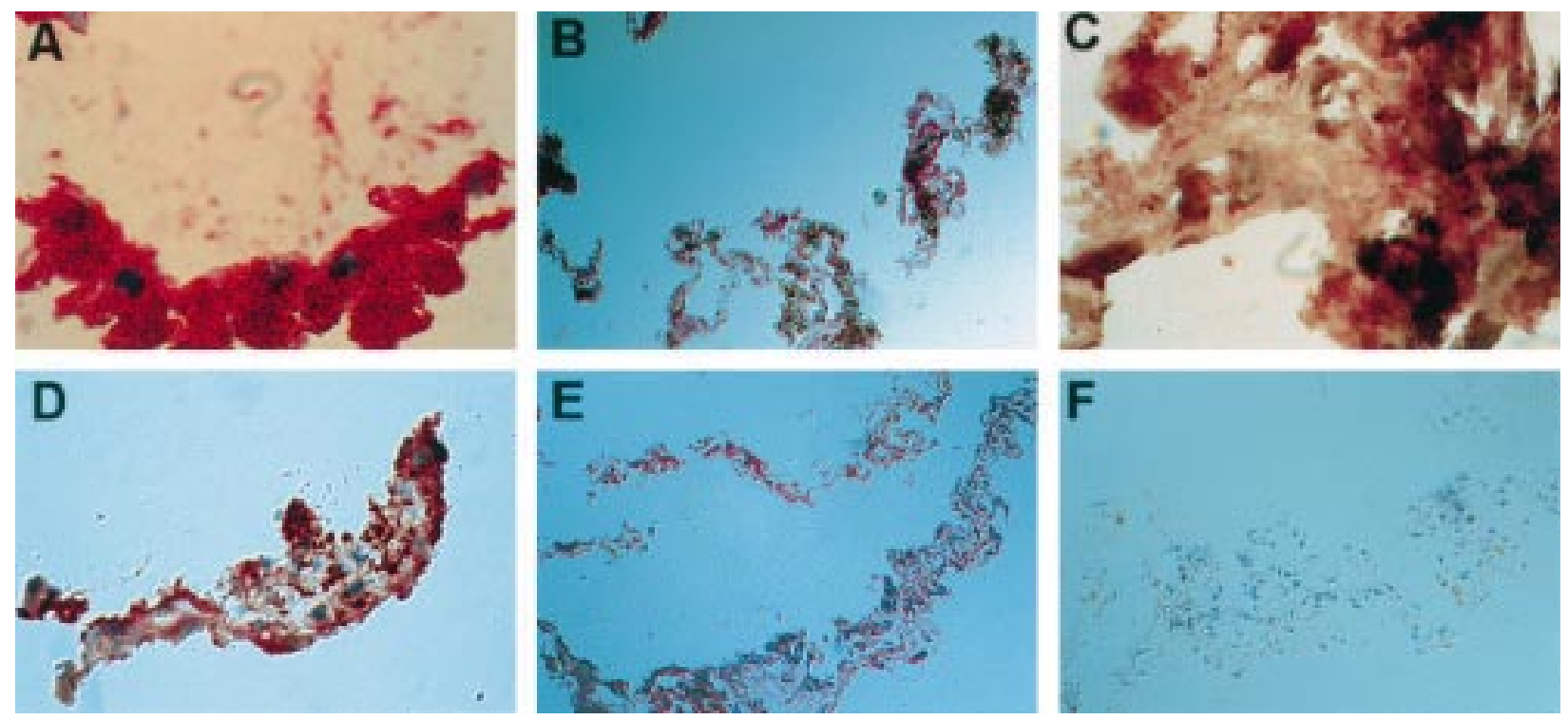

Figure 3 Immunostaining for VEGF and its receptors in ERMs. (A) VEGF positivity in RPE cells containing melanin granules from a subfoveal choroidal neovascular membrane. (B) Flt-1 positivity in RPE cells containing melanin granules from a PVR ERM. (C) Double labelling for VEGF and class III $\beta$ tubulin demonstrates VEGF localisation within RPE cells in a postretinal detachment ERM. VEGF is visualised with AEC and class III $\beta$ tubulin with HistoMark Black. Since class III $\beta$ tubulin is a marker for identifying RPE cells in ERMs, co-localisation of both colour reaction products indicates that VEGF is localised to RPE cells. (D) Nearly all of the cells in a retroretinal membrane are positive for glial fibrillary acidic protein, a marker for glial cells. (E) Another section from the same membrane illustrated in (D) showing nearly all of the cells are positive for flt-1, suggesting that glial cells express flt-1. (F) A portion of a serial section to that illustrated in (E) in which the anti-ft-1 antibodies had been preincubated with a tenfold molar excess of the peptide against which they were generated is devoid of staining, demonstrating the specificity of flt-1 staining (HistoMark Red/haematoxylin, $A, B$, $E, F ; A E C /$ haematoxylin, $D ; A, C \times 390 ; B, D \times 155 ; E, F \times 78)$.

$3 \mathrm{C}-\mathrm{E})$, suggesting that the flt-1 receptors are also expressed by retinal glial cells.

CELL CULTURES

Immunohistochemistry for flt-1 and flk-1/ KDR was performed on cultured RPE and retinal glia. RPE cells showed staining for flt-1 and flk-1/KDR along cell surfaces (Fig 5). The staining for flt- 1 and flk-1/KDR was equivocal in retinal glial cells because of high background staining not seen in RPE cells, but VEGF positivity was clearly demonstrated, both in RPE cells and retinal glia (not shown). The expression of flt-1 and flk-1/KDR was also investigated by RT-PCR. Reaction products with the correct size for flt-1 (521 bp) and flk-1/KDR (537 bp) were amplified from RNA isolated from cultured RPE and from RPE isolated from postmortem human eyes (Fig 6). They were confirmed to be flt- 1 and flk-1/KDR fragments by sequencing. RNA harvested from cultured retinal glia showed an appropriate reaction product for flt-1, but not flk-1/KDR.

\section{Discussion}

Growth factors appear to be involved in the formation and progression of epiretinal membranes. One of the most studied of these factors is PDGF. Immunohistochemical staining for PDGF and its receptors has been demonstrated in both vascular and avascular ERMs. ${ }^{11} 2829$ This is an expected finding because PDGF is produced by vascular endothelial cells ${ }^{49}$ and RPE cells, ${ }^{1150}$ and
A

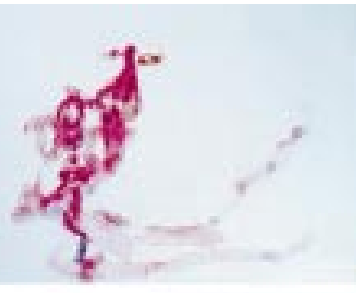

D

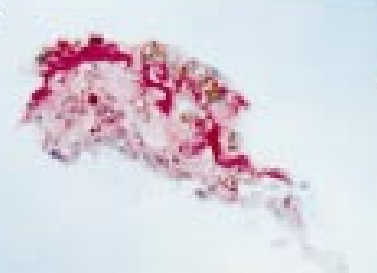

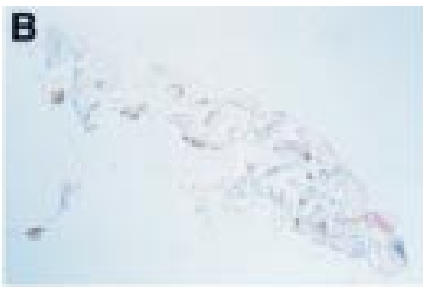

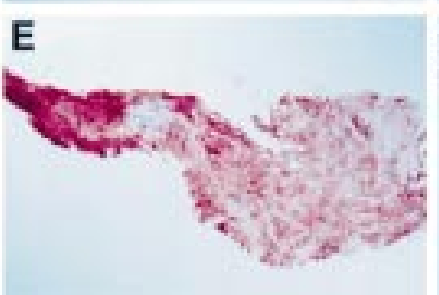

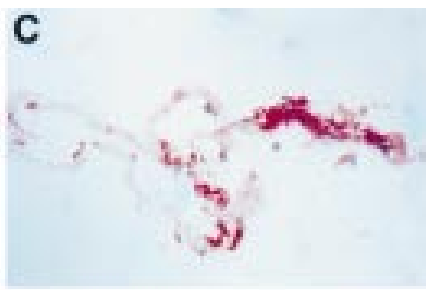

$\mathbf{F}$

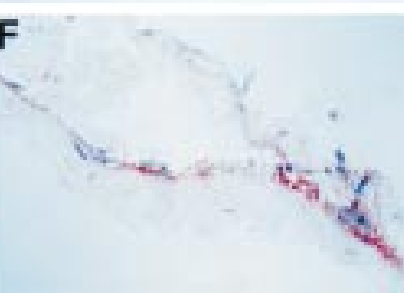

Figure 4 Immunostaining for VEGF receptors in non-vascularised ERMs is visualised with a red reaction product. (A) Flt-1 staining in a PVR ERM. (B) Preincubation of the primary antibody with the peptide against which it was generated eliminates most immunostaining in the same ERM shown in $(A)$. (C) Flt-1 positivity is demonstrated in an idiopathic ERM. (D) Flk-1 immunostaining in a subretinal membrane from a patient with PVR. (E) Flk-1 immunostaining in a PVR ERM. (F) Flk-1 immunostaining in an idiopathic ERM. (HistoMark Red/haematoxylin; $A, B, C, D, F \times 145, E$ $\times 70)$. 

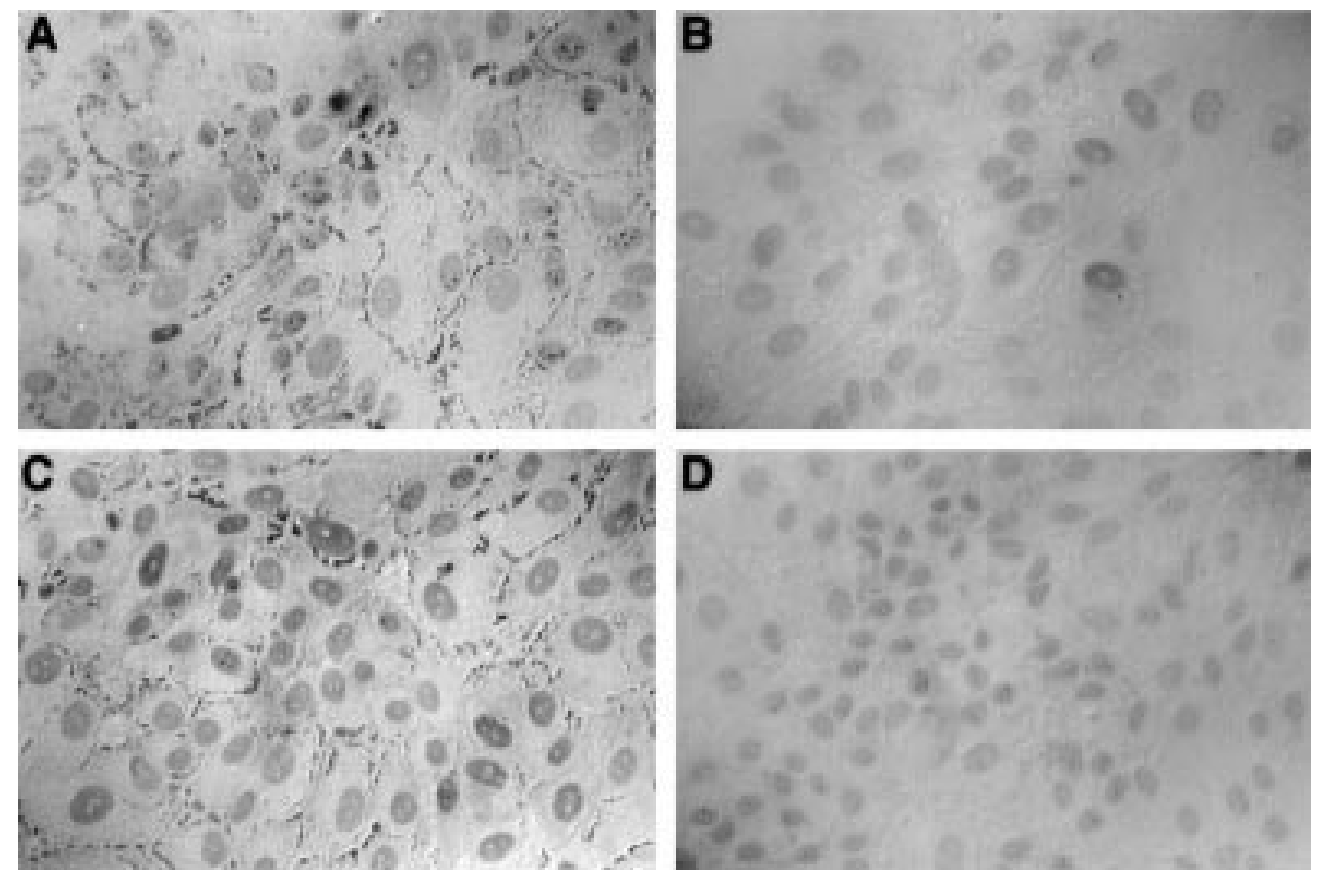

Figure 5 Immunostaining for VEGF receptors in cultured RPE cells is visualised with a red reaction product. (A) Flt-1 immunostaining is demonstrated on the surface membranes of RPE cells cultured in monolayer. (B) Preincubation of the primary antibody with the peptide against which it was generated eliminates the staining. (C) Flk-1 immunostaining is also demonstrated on the surface membranes of cultured RPE cells and is almost entirely eliminated by preincubation of the antibody with the control peptide (D). (HistoMark Red/haematoxylin, $\times 215$ ).

A

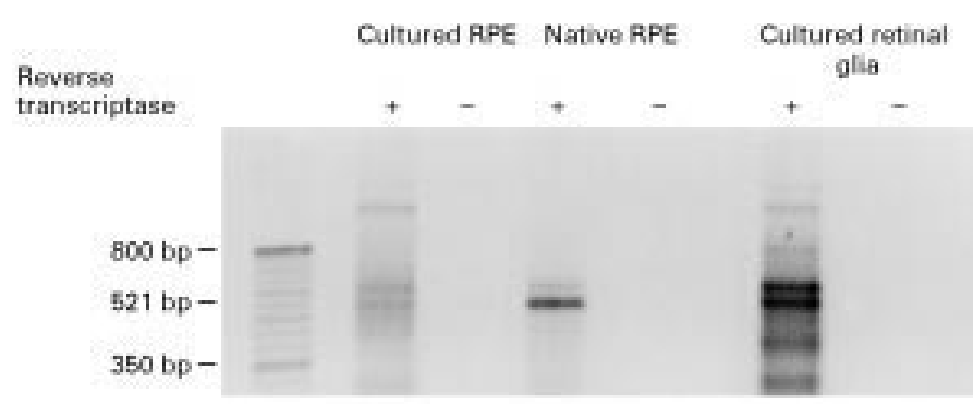

B

Cultured RPE Native RPE

Reverse transcriptase

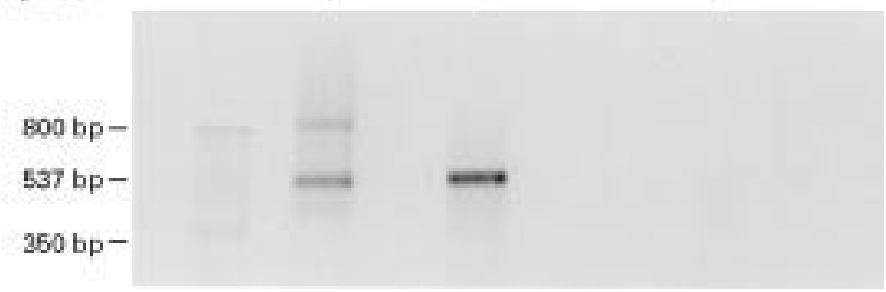

Figure 6 Retinal pigmented epithelial (RPE) cells contain $m R N A$ for the VEGF receptors, ftt-1 and flk-1. Total RNA (1 $\mu \mathrm{g})$ isolated from cultured RPE, native RPE, or retinal glia was incubated with $(+)$ or without $(-)$ reverse transcriptase and then run in polymerase chain reactions using the specific primers for flt-1 $(A)$ or flk-1 (B) listed in the Methods section. Sequencing was used to confirm that the $521 \mathrm{bp}$ band in $A$ was the predicted fragment of flt-1 and the $537 \mathrm{bp}$ band in $B$ was the predicted fragment of flk-1. Cultured and native RPE contain $m R N A$ for flt-1 and flk-1, while only flt-1 $m R N A$ was detected in retinal glia.
PDGF receptors are found on $\mathrm{RPE}^{11}$ and retinal glial cells. ${ }^{50}$ PDGF has been shown to be an autocrine growth stimulator for RPE cells and it may play an important role in the progression of ERMs.

However, several other growth factors have been localised to ERMs ${ }^{3051}$ and so for comparative purposes, we performed immunohistochemical staining for PDGF-A, PDGF-B, VEGF, TGF- $\beta_{1}$, TGF- $\beta_{2}$, TGF- $\beta_{3}$, and bFGF. Staining for VEGF was just as prominent as staining for PDGF, both in terms of the total number of ERMs that showed VEGF immunoreactivity and the number of cells within individual ERMs that were VEGF positive. Compared with PDGF and VEGF, staining for the TGF- $\beta$ isoforms and bFGF was less frequent and less extensive in ERMs. While VEGF positive cells were particularly abundant and intensely stained in vascular membranes, VEGF staining was also prominent in avascular membranes. In retrospect, this is not that surprising because retinal glia and RPE each produce $\mathrm{VEGF}^{52-55}$ and both cell types are present in vascular and avascular ERMs. However, this finding raises two questions: (1) If VEGF is present in avascular membranes, why are there no blood vessels? (2) Is it possible that there are cells other than vascular endothelial cells that are targeted by VEGF?

With respect to the first question, there is strong evidence implicating VEGF in the development of retinal neovascularisation in ischaemic retinopathies ${ }^{14-21}$ and it may even be a necessary component, but it may not be the only factor involved. There is mounting 
evidence suggesting that while VEGF is angiogenic on chick chorioallantoic membrane and in the rabbit corneal pocket model, high levels may be needed to cause neovascularisation in the retina in some species. ${ }^{56}$ Immunoreactive VEGF is increased in the retina in several conditions in which neovascularisation does not occur ${ }^{57}$ and repeated injection or sustained release of VEGF in the vitreous cavity of primates does not cause unequivocal neovascularisation. ${ }^{56}{ }^{59}$ It is possible that the presence of endothelial growth inhibitory factors, such as TGF- $\beta$, which may be secreted by glial cells, ${ }^{60}$ may prevent VEGF from exerting its angiogenic activity. The presence of VEGF in ERMs in the absence of neovascularisation is consistent with these other observations.

To address the second question, we investigated the expression of flt- 1 and flk-1/KDR in $\mathrm{RPE}$ and retinal glia which, as noted above, are the predominant cell types in ERMs. As demonstrated by immunocytochemistry and RTPCR, flt-1 and flk-1/KDR are expressed in cultured RPE. Appropriate fragments for flt- 1 and flk-1/KDR are also amplified from RPE RNA from postmortem human eyes. While RNA from photoreceptors may contaminate RPE RNA, there is not likely to be any RNA from vascular endothelial cells because retinal vessels are located in the inner part of the retina and the retina was removed before isolation. In addition, Bruch's membrane was examined and found to be intact after RPE isolation, precluding contamination by choroidal vessels. This suggests that RPE in situ, as well as RPE in epiretinal membranes and in culture, express flt- 1 and flk-1/KDR. The situation is less clear for retinal glia, but based upon RT-PCR, cultured retinal glia can express flt-1 and staining for flt- 1 in the majority of cells in predominantly glial ERMs suggests that the same is true for retinal glial cells in ERMs.

These findings conflict with the dogma that flt- 1 and flk-1/KDR are endothelial cell specific; they add to the growing body of evidence indicating that cell types other than vascular endothelial cells including neural progenitor cells of the retina, ${ }^{61}$ corneal endothelial cells, ${ }^{62}$ renal mesangial cells, ${ }^{63}$ and melanoma cells $^{64}$ possess VEGF receptors. In addition, our data strongly support the recent findings of Guerrin et $a l^{65}$ who demonstrated that cultured RPE cells express flt- 1 and flk-1/KDR and contain an autocrine loop for VEGF. In many ERMs, VEGF and its receptors were co-localised, suggesting that an autocrine and/or paracrine mechanism may be operative. The present study suggests that autocrine loops for both PDGF and VEGF may be involved in progression of both vascular and avascular ERMs.

This study was supported by PHS grants EY05951, EY10017, and core grant P30EY01765 from the National Eye Institute, Bethesda, MD and a Lew R Wasserman Merit Award (PAC) and an unrestricted grant from Research to Prevent Blindness, Inc, New York. Antibodies to TGF- $\beta_{1}$, TGF- $\beta_{2}$, and TGF- $\beta_{3}$ Inc, New York. Antibodies to TGF- $\beta_{1}$, TGF- $\beta_{2}$, and TGF- $\beta_{3}$
were kindly provided by K Flanders. Antibodies to bFGF were were kindly provided by K Flanders. Antibodies to bFGF were by A Frankfurter, HistoMark Red and HistoMark Black kits were provided by $\mathrm{T}$ Woerner (Kirkegaard and Perry). We wish to thank Carol Merges for assistance with immunohistochemistry.

1 Clarkson JG, Green WR, Masof D. A histopathologic review of 168 cases of preretinal membrane. Am $\mathcal{f}$ Ophthalmol of 168 cases

2 Hiscott PS, Grierson I, McLeod D. Retinal pigment epitheial cells in epiretinal membranes: an immunohistochemical study. Br 7 Ophthalmol 1984;68:708-15.

3 Hiscott PS, Grierson I, Trombetta CJ, Rahi AHS, Marshall J, McLeod D. Retinal and epiretinal glia: an immunohistochemical study. Br f Ophthalmol 1985;68:698-707.

4 Kampik A. Kenyon KR, Michels RG, Green WR, de la Cruz $Z C$. Epiretinal and vitreous membranes: comparative study of 56 cases. Arch Ophthalmol 1981;99:1445-54.

5 Vinores SA, Campochiaro PA, Conway BP. Ultrastructural and electronimmunocytochemical characterization of cells in epiretinal membranes. Invest Ophthalmol Vis $S_{C i}$ 1990;31:14-28.

6 Cowley M, Conway BP, Campochiaro PA, Kaiser D, Gaskin $\mathrm{H}$. Clinical risk factors for proliferative vitreoretinopathy. Arch Ophthalmol 1989;107:1147-51.

7 The Retina Society Terminology Committee. The classification of retinal detachment with proliferative vitreoretinopathy. Ophthalmology 1983;90:121-5.

8 Campochiaro PA, Glaser BM. A retina-derived stimulaCampochiaro PA, Glaser BM. A retina-derived stimula-
tor(s) of retinal pigment epithelial cell and astrocyte proliferation. Exp Eye Res 1986;43:449-57.

9 Campochiaro PA, Bryan JA, III, Conway BP, Jaccoma EH. Intravitreal chemotactic and mitogenic activity. Implication of blood-retinal barrier breakdown. Invest Ophthalmol Vis Sci 1986;27(Suppl): 188

10 Sen HA, Campochiaro PA. Intravitreous injection of adenosine or its agonists cause breakdown of the blood-retinal barrier. Arch Ophthalmol 1989;107:1364-7.

11 Campochiaro PA, Hackett SF, Vinores SA, Freund J, Csaky $\mathrm{C}$, LaRochelle W, et al. Platelet-derived growth factor is an autocrine growth stimulator in retinal pigmented epithelial cells. F Cell Sci 1994;107:2459-69.

12 Plate KH, Breier G, Welch HA, Risau W. Vascular endothelial growth factor is a potential tumour angiogenesis factor in human gliomas in vivo. Nature 1992;359:845-8.

13 Shweiki D, Itin A, Soffer D, Keshet E. Vascular endothelial growth factor induced byhypoxia may mediate hypoxiagrowth factor induced byhypoxia may mediate

14 Adamis AP, Miller JS, Bernal MT, D'Amico DJ, Folkman J, Yeo TK, et al. Increased vascular endothelial growth factor levels in the vitreous of eyes with proliferative diabetic retinopathy. Am f Ophthalmol 1994;118:445-50.

5 Aiello LP, Avery RL, Arrigg PG, Keyt BA, Jampel HD, Shah $\mathrm{ST}$, et al. Vascular endothelial growth factor in ocular fluid of patients with diabetic retinopathy and other retinal disorders. N Engl f Med 1994;331:1480-7.

16 Aiello LP, Pierce EA, Foley ED, Takagi H, Chen H, Riddle $\mathrm{L}$, et al. Suppression of retinal neovascularization in vivo by inhibition of vascular endothelial growth factor (VEGF) using soluble VEGF-receptor chimeric proteins. Proc Nat Acad Sci USA 1995;92:10457-61.

17 Malecaze F, Clamens S, Simorre-Pinatel V, Mathis A, Chollet P, Favard C, et al. Detection of vascular endothelial growth factor messenger RNA and vascular endothelial growth factor-like activity in proliferative diabetic retinopathy. Arch Ophthalmol 1994;112:1476-82.

18 Miller JW, Adamis AP, Shima DT, D'Amore PA, Moulton RS, O'Reilly MS, et al. Vascular endothelial growth factor/ vascular permeability factor is temporally and spatially correlated with ocular angiogenesis in a primate model. Am $\mathcal{F}$ Path 1994;145:574-84.

19 Pe'er J, Shweiki D, Itin A, Heme I, Gnessin H, Keshet E. Hypoxia-induced expression of vascular endothelial growth factor by retinal cells is a common factor in neovascularizing ocular diseases. Lab Invest 1995;72:638-45.

20 Pe'er J, Folberg R. Itin A, Gnessin H, Hemo I, Keshet E. Upregulated expression of vascular endothelial growth factor in proliferative diabetic retinopathy. $\mathrm{Br} \mathcal{F}$ Ophthalmol 1996;80:241-5.

21 Pierce EA, Avery RL, Foley ED, Aiello LP, Smith LEH. Vascular endothelial growth factor/vascular permeability factor expression in a mouse model of retinal neovascularization. Proc Natl Acad Sci USA 1995;92:905-9.

22 DeVries C, Esobedo JA, Ueno H, Houck K, Ferrara N, Williams LT. The fms-like tyrosine kinase, a receptor for
vascular endothelial growth factor. Science 1992;255:98991 .

23 Terman BI, Dougher-Vermazen M, Carrion ME, Dimitrov $\mathrm{D}$, Armellino DC, Gospodarowicz D, et al. Identification of the KDR tyrosine kinase as a receptor for vascular endothelial cell growth factor. Biochem Biophys Res Commun 1992;187:1579-86.

24 Quinn TP, Peters KG, DeVries C, Ferrara N, Williams LT. Fetal liver kinase 1 is a receptor for vascular endothelial growth factor and is selectively expressed in vascular endothelium. Proc Natl Acad Sci USA 1993;90:7533-7.

25 Sivalingam A, Kenney J, Brown GC, Benson WE, Donoso L. Blast fibroblast growth factor levels in the vitreous of patients with proliferative diabetic retinopathy. Arch Ophthalmol 1990;108:869-72.

26 Hanneken A, deJuan E, Jr, Lutty GA, Fox GM, Schiffer S, Hjelmeland LM. Altered distribution of basic fibroblast growth factor in diabetic retinopathy. Arch Ophthalmol growth factor in diab

27 Pournaras CJ, Tsacopoulos M, Strommer K, Gilodi N, Leuenberger PM. Scatter photocoagulation restores tissue 
hypoxia in experimental vasoproliferative microangiopathy

28 in miniature pigs. Ophthalmology 1990;97:1329-33. $\mathrm{JE}$, Westra I, et al. Platelet-derived growth factor ligands and receptors immunolocalized in proliferative retinal diseases. Invest Ophthalmol Vis Sci 1994;35:3649-63.

29 Vinores SA, Henderer JD, Mahlow J, Chiu C, Derevjanik NL, LaRochelle W, et al. Isoforms of platelet-derived growth factor and its receptors in epiretinal membranes: immunolocalization to retinal pigmented epithelial cells. Exp Eye Res 1995;60:607-19.

30 Campochiaro PA, Hackett SF, Vinores SA. Growth factors in the retina and retinal pigmented epithelium. Prog Retinal Eye Res 1996;15:547-67.

31 Barthel LK, Raymond PA. Improved method for obtaining 3- $\mu \mathrm{m}$ cryosections for immunocytochemistry. f Histochem Cytochem 1990;38:1383-8.

32 Campochiaro PA, Jerdan JA, Glaser BM. The extracellular matrix of human retinal pigment epithelial cells in vivo and matrix of human retinal pigment epithelial cells in vivo and $1615-21$.

33 Leschey KH, Hackett SF, Singer JH, Campochiaro PA. Growth factor responsiveness of human retinal pigmen epithelial cells. Invest Ophthalmol Vis Sci 1990;31:839-46.

34 Vinores SA, Campochiaro PA, McGehee R, Orman W, Hackett SF, Hjelmeland LM. Ultrastructural immunocytochemical changes in RPE, retinal glia, and fibroblasts in vitreous culture. Invest Ophthalmol Vis Sci 1990;31:252945.

35 Lutty GA, Merges C, Threlkeld A, Crone C, McLeod D. Heterogeneity in localization of isoforms of TGF- 3 in human retina, vitreous and choroid. Invest Ophthalmol Vis Sci 1993;34:477-87.

36 Raines EW, Dower SK, Ross R. Interleukin-1 mitogenic activity for fibroblast and smooth muscle cells is due to PDGFAA. Science 1989; 243:393-6.

37 LaRochelle WJ, Robbins KC, Arinson SA. Immunochemical localization of the epitope for a monoclonal antibody cal localization of the epitope for a monoclonal antibody that neutralizes human platelet-derived grow

38 Lutty GA, Merges C, Crone S, McLeod DS. Immunohistochemical insights into sickle cell retinopathy. Curr Eye Res 1994;13:125-38.

39 Reilly TM, Taylor DS, Herblin WF, Thoolen MJ, Chiu AT, Watson DW, et al. Monoclonal antibodies directed agains basic fibroblast growth factor which inhibit its biological activity in vitro and in vivo. Biochem Biophys Res Com 1989; 164:736-43.

40 Vinores SA, Herman MM, Hackett SF, Campochiaro PA. A morphological and immunohistochemical study of human retinal pigment epithelial cells, retinal glia, and fibroblasts grown on Gelfoam matrix in an organ culture system. A comparison of structural and nonstructural proteins and their application to cell type identification. Graefes Arch Clin Exp Ophthalmol 1993;231:279-88.

41 Vinores SA, Derevjanik NL, Mahlow J, Haller JA, DeJuan $\mathrm{E}$, Frankfurter A, et al. Class III B-tubulin in human retinal pigment epithelial cells in culture and in epiretinal pigment epithelial cells in culture and

42 Vinores SA, Vinores MA, Chiu C, Woerner TM, Campochiaro PA. Double-labelling for keratin and class III $\beta$-tubulin within cultured retinal pigment epithelial cells: comparison within cultured retinal pigment epithelial cells: comparison of chromogens to yield maximum resolution of two structural proteins within the same cell. $\mathcal{f}$ Histotechno 1997;20:19-25.

43 Mandriota SJ, Menoud P-A, Pepper MS. Transforming growth factor $\beta_{1}$ down-regulates vascular endothelia growth factor receptor $2 / \mathrm{flk}-1$ expression in vascular endothelial cells. F Biol Chem 1996;271:11500-5.

44 Berard M, Sordello S, Ortega N, Carrier J-L, Peyri N, Wassef M, et al. Vascular endothelial growth factor confers a growth advantage in vitro and in vivo to stromal cells cultured from neonatal hemangiomas. Am $\mathcal{F}$ Pathol 1997;150: 1315-26.

45 Charmock-Jones DS, Sharkey A, Boocock CA, Ahmed A Plevin R, Ferrara N, et al. Vascular endothelial growth fac-
tor receptor localization and activation in human trophobtor receptor localization and activation in human trophoblast 30 .

46 Ahmed A, Li XF, Dunk L, Whittle MJ, Rushton DI, Rollason T. Colocalization of vascular endothelial growth factor and its flt-1 receptor in human placenta. Growth Factor 1995;12:235-43

47 Chomczynski P, Sacchi N. Single step of RNA isolation by acid guanidinium thiocyanate phenol-chloroform extraction. Anal Biochem 1987;162:156-9.
48 Jakeman LB, Winer J, Bennett GL, Altar CA, Ferrara N. Binding sites for vascular endothelial growth factor are localized on endothelial cells in adult rat tissues. Clin Invest 1992;89:244-53.

49 Storksen NF, Harsh GR, Gibbs VC, Williams LT. Regulated expression of the platelet-derived growth factor A chain gene in microvascular endothelial cells. F Biol Chem 1987; 262:14381-4.

50 Mudhar HS, Pollock RA, Wang C, Stiles CD, Richardson WD. PDGF and its receptors in the developing rodent retina and optic nerve. Development 1993;118:539-52.

51 Frank RN, Amin RH, Eliott D, Puklin JE, Abrams GW. Basic fibroblast growth factor and vascular endothelial growth factor are present in epiretinal and choroidal neovascular membranes. Am f Ophthalmol 1996;122:393403.

52 Adamis AP, Shima DT, Yeo K-T, Yeo TK, Brown LF, Berse $\mathrm{B}$, et al. Synthesis and secretion of vascular permeability factor/vascular endothelial growth factor by human retinal pigment epithelial cells. Biochem Biophys Res Comm 1993;193:631-8.

53 Hata Y, Nakagawa K, Ishibashi T, Inomata $H$, Ueno $H$, Sueishi K. Hypoxia-induced expression of vascular endothelial growth factor by retinal glial cells promotes in vitro angiogenesis. Virchows Archiv 1995;426:479-86.

54 Kvanta A. Expression and regulation of vascular endothelial growth factor in choroidal fibroblasts. Curr Eye Res 1995;14:1015-20.

55 Lopez PF, Sippy BD, Lambert HM, Thack AB, Hinton DR. Transdifferentiated retinal pigment epithelial cells are immunoreactive for vascular endothelial growth factor in surgically excised age-related macular degeneration-related choroidal neovascular membranes. Invest Ophthalmol Vis Sci 1996;37:855-68.

56 Ozaki H, Hayashi H, Vinores SA, Moromisato Y, Campochiaro PA, Oshima K. Intravitreal sustained release of VEGF causes retinal neovascularization in rabbits and breakdown of the blood-retinal barrier in rabbits and primates. Exp Eye Res 1997;64:505-17.

57 Vinores SA, Küchle M, Mahlow J, Chiu C, Green WR, Campochiaro PA. Blood-ocular barrier breakdown in eyes with ocular melanoma: a potential role for vascular endothelial growth factor. Am f Pathol 1995;147:1289-97.

58 Vinores SA, Youssri AI, Luna JD, Chen Y-S, Bhargave S, Vinores MA, et al. Upregulation of vascular endothelial growth factor in ischemic and non-ischemic human and experimental retinal disease. Histol Histopathol 1997;12:99109.

59 Tolentino MJ, Miller JW, Gragoudas ES, Jakobiec FA, Flynn $\mathrm{E}$, Chatzistefanou $\mathrm{K}$, et al. Intravenous injections of vascular endothelial growth factor produce retinal ischemia and microangiopathy in an adult primate. Ophthalmology 1996; 103:1820-8.

60 Behzadian MA, Wang XL, Jiang B, Caldwell RB. Angiostatic role of astrocytes-suppression of vascular endothelial cell growth by TGF- 13 and other inhibitory factor(s). Glia 1995;15:480-90.

61 Yang X, Cepko CL. Flk-1, a receptor for vascular endothelial growth factor (VEGF), is expressed by retinal progenitor cells. I Neurosci 1996; 16:6089-99.

62 Bednarz J, Weich HA, Rodokanaki-von Schrenck A, Engelmann $K$. Expression of genes coding growth factors and growth factor receptors in differentiated and dedifferentiated human corneal endothelial cells. Cornea 1995;14:37281.

63 Takahashi T, Shirasawa T, Miyake K, Yahagi Y, Maruyama $\mathrm{N}$, Kasahara N, et al. Protein tyrosine kinases expressed in glomeruli and cultured glomerular cells: Flt-1 and VEGF expression in renal mesangial cells. Biochem Biophys Res expression in renal mesa

64 Cohen T, Gitay-Goren H, Sharon R, Shibuya M, Halaban $\mathrm{R}$, Levi BZ, et al. VEGF 121, a vascular endothelial growth factor (VEGF) isoform lacking heparin binding ability, requires cell-surface heparin sulfates for efficient binding to the VEGF receptors of human melanoma cells. $7 \mathrm{Biol} \mathrm{Chem}$ 1995;270:11322-6.

65 Guerrin M, Moukadiri H, Chollet P, Moro F, Dutt K, Malecaze F, et al. Vasculotropin/vascular endothelial growth factor is an autocrine growth factor for human retinal pigment epithelial cells cultured in vitro. $\mathcal{F}$ Cell Physiol 1995;164:385-94. 